\title{
Interactive comment on "Altitude profiles of CCN characteristics across the Indo-Gangetic Plain prior to the onset of the Indian summer monsoon" by Venugopalan Nair Jayachandran et al.
}

Venugopalan Nair Jayachandran et al.

sureshsplvssc@gmail.com

Received and published: 10 November 2019

Interactive comment on "Altitude profiles of CCN characteristics across the IndoGangetic Plain prior to the onset of the Indian summer monsoon" by Venugopalan Nair Jayachandran et al is uploaded in the form of supplement

Please also note the supplement to this comment: https://www.atmos-chem-phys-discuss.net/acp-2019-571/acp-2019-571-AC1supplement.pdf 
2019.

ACPD

Interactive

comment

Printer-friendly version

Discussion paper 